\title{
Microbiological and chemical assessment of spring water from a rural setting in Ondo State Southwest, Nigeria
}

\author{
Saka A. Balogun ${ }^{1 \star}$, Benjamin C. Ejelonu ${ }^{2}$, Adebayo A. Lasisi ${ }^{3}$ and Abideen I. Adeogun ${ }^{3}$ \\ ${ }^{1}$ Environmental Microbiology and Biotechnology Unit, Department of Microbiology, Federal University of Agriculture, \\ Abeokuta, PMB 2240, Abeokuta, Ogun State, Nigeria. \\ ${ }^{2}$ Department of Chemistry, Adekunle Ajasin University, Akungba-Akoko, PMB 001, Akungba-Akoko, \\ Ondo State, Nigeria. \\ ${ }^{3}$ Dept of Chemistry, Federal University of Agriculture, Abeokuta, PMB 2240, Ogun state, Nigeria.
}

Accepted 20 June, 2013

\begin{abstract}
Assessment of spring water from Ikare-Akoko, a rural setting in southwest, Nigeria for microbial and chemical contaminants was carried out. Total heterotrophic bacteria count of $4.0 \times 10^{6} \mathrm{CFU} / \mathrm{mL}$ was highest during the peak of the rainy season in Omi-idu spring (Igbede community) while the lowest population of $0.14 \times 10^{6} \mathrm{CFU} / \mathrm{mL}$ was in Agadagidi spring (Ishakunmi community). The highest coliform population of $2.8 \times 10^{6} \mathrm{CFU} / \mathrm{mL}$ was at Isunpaiye (Oyinmo community), while the lowest value of 0.19 $\times 10^{6} \mathrm{CFU} / \mathrm{mL}$ was recorded at Agadagidi (Ishakunmi). The multiple tube fermentation technique was employed to determine the most probable number (MPN) of coliforms per $100 \mathrm{~mL}$ of water sample. The highest MPN/100 mL value of $76 \pm 2.1$ for coliforms was recorded at Isunpaiye while the lowest value of $5.1 \pm 2.1$ was in Agadagidi spring. Physico-chemical properties of the spring waters were mostly within the WHO benchmark for potable water. Arae had the highest total dissolved solids (TDS) value of 969 $\mathrm{mgL}^{-1}$ (benchmark, $500 \mathrm{mg} / \mathrm{L}$ ), total hardness values were normal except at Arae $(260 \mathrm{mg} / \mathrm{L})$. Heavy metals levels in the spring water were generally low except in Omi-idu spring.
\end{abstract}

Key words: Rural setting, spring water, heterotrophic bacteria, coliform bacteria, physico-chemical properties, heavy metals.

\section{INTRODUCTION}

Population increase over the past century has resulted in increase pressure on water resources of the developed and developing countries. These pressures involve the contamination from domestic, industrial and agricultural wastes, less direct effects caused by climate change and other ecological disturbances. Population growth pattern suggests that these pressures can only increase without adequate and appropriate interventions. Without adequate interventions, waterborne diseases pandemic or epidemic can happen and increase dramatically (Ford and Colwell, 1996). The major concern of people in deve- loping countries is that of obtaining clean water. In Africa and Asia, most of the large cities utilize surface water but many millions of people in peri-urban communities and rural areas are dependent on groundwater (Obiri-Danso et al., 2009).

Groundwater is generally understood to mean all the water underground, occupying the void within geological formations. It is simply the most important components and constitutes of about two-thirds of the fresh-water resources of the world. If the polar ice caps and glaciers are not considered, groundwater accounts for nearly $95 \%$ 
Table 1. Mean total heterotrophic bacteria (THBC) and total coliform counts (TCC) of spring and borehole water samples from lkare-Akoko, communities.

\begin{tabular}{|c|c|c|c|c|c|c|c|c|}
\hline \multirow[t]{2}{*}{ Water source } & \multicolumn{2}{|c|}{$\begin{array}{c}\text { Onset of dry season } \\
\text { mean count } \times 10^{6} \\
\text { CFU/mL }\end{array}$} & \multicolumn{2}{|c|}{$\begin{array}{c}\text { Peak of dry season } \\
\text { mean count } \times 10^{6} \\
\text { CFU/mL }\end{array}$} & \multicolumn{2}{|c|}{$\begin{array}{l}\text { Onset of rainy season } \\
\text { mean count } \times 10^{6} \\
\text { CFU/mL }\end{array}$} & \multicolumn{2}{|c|}{$\begin{array}{c}\text { Peak of rainy } \\
\text { season mean count } \\
\times 10^{6} \mathrm{CFU} / \mathrm{mL}\end{array}$} \\
\hline & THBC & TCC & THBC & TCC & THBC & TCC & THBC & TCC \\
\hline Arae & 0.45 & 0.2 & 0.18 & 0.15 & 0.21 & 0.07 & 0.47 & 0.28 \\
\hline Omi-idu & 2.0 & 1.01 & 0.8 & 0.71 & 1.91 & 0.87 & 4.0 & 1.64 \\
\hline Akasabo & 0.93 & 0.63 & 0.25 & 0.2 & 0.62 & 0.27 & 1.31 & 0.75 \\
\hline Ashonmo & 1.05 & 0.60 & 0.45 & 0.31 & 0.6 & 0.26 & 1.50 & 0.86 \\
\hline Isunpaiye & 2.04 & 1.04 & 0.84 & 0.70 & 1.60 & 0.92 & 3.93 & 2.80 \\
\hline Gurusi & 0.98 & 0.84 & 0.45 & 0.33 & 0.8 & 0.50 & 1.96 & 1.23 \\
\hline Agadagidi & 0.4 & 0.19 & 0.14 & 0.083 & 0.28 & 0.14 & 0.5 & 0.24 \\
\hline
\end{tabular}

THBC, Total heterotrophic bacteria count; TCC, total coliform count.

of all usable freshwater. Lakes, swamps, reservoirs and rivers accounts for $3.5 \%$ while soil moisture accounts for the remaining 1.5\% (Freeze and Cherry, 1979).

In the rural areas of the United States, $96 \%$ of domestic water is supplied from ground water (USGS, 2000). In Latin America, some of the largest cities like Mexico City, Lima, Buenos Aires and Santiago obtain a significant proportion of their municipal water from groundwater (Foster et al., 2010). In Africa and Asia, most of the big cities use surface water, but many millions of people in the rural areas are dependent on groundwater (Nkansah and Ephraim, 2009). Spring water, a form of groundwater that comes to the surface (Chilton and West, 1992), through recharge by surface water (Taylor and Howard, 1996) has been a veritable source of potable water in Ikare-Akoko, since tap water is in short supply. IkareAkoko is a rural setting in Akoko North East Local Government of Ondo State, south west Nigeria. It is the rallying point for the Akokos, a major ethnic group in the state. Ikare-Akoko is about $80 \mathrm{~km}$ from Akure the state capital, with about one hundred and seventy-five thousand people as at 2001 (NPC, 2001). Hence, the need to carry out microbiological and chemical evaluation of the spring water supplies with the aim of determining the suitability of the water for consumption by the various communities in this town.

\section{MATERIALS AND METHODS}

One hundred milliliters of water from springs in different communities in lkare-Akoko were used. The communities and the springs sampled were: Odoruwa community (Arae and Akasabo springs), Okoja community (Ashonmo spring), Ekan community (Gurusi spring), Igbede community (Omi-idu spring), Ishakunmi community (Agadagidi spring) and Oyinmo community (Isunpaiye spring). The springs were sampled from March to October, 2009 (rainy season) and November to February, 2010 (dry season). Samples were collected aseptically in sterile glass bottles. Samples were collected in triplicates and transported in iced chest to the laboratory. Plate count agar and MacConkey agar (International Diagnostics Group Plc, USA) were used to determine the total heterotrophic bacterial count (THBC) and total coliform counts (TCC) in water samples. Qualitative and quantitative assays for coliforms that involved the presumptive, confirmed and the completed tests in the multiple tube fermentation technique was carried out to determine the most probable number (MPN) of coliforms in the water sample (APHA, 1992). Furthermore, Escherichia coli strains were characterized and identified according to the Bergey's Manual of Systematic Bacteriology.

Physico-chemical parameters such as: Temperature, turbidity, $\mathrm{pH}$, electrical conductivity and total dissolved solids were determined in situ with a combined $\mathrm{pH} / \mathrm{EC} / \mathrm{TDS}$ meter (Combo $\mathrm{HI}$ 98130, Hanna, USA). The colour of the water was determined using the Platinum-Cobalt method, while chloride level was determined using titrimetry method (Ademoroti, 1996). Ultra-violet spectrophotometer was used for the determination of nitrate concentration and total suspended solids (TSS) of the water samples based on the standard methods of APHA/AWWA/WPCF (1998). The presence of heavy metals $(\mathrm{Cr}, \mathrm{Cd}$, $\mathrm{Co}, \mathrm{Cu}, \mathrm{Mn}, \mathrm{Fe}, \mathrm{Sn}, \mathrm{Se}, \mathrm{Ni}, \mathrm{Pb}$ and $\mathrm{Zn}$ ) residue in the spring water samples were analyzed using graphite-furnace atomic absorption spectro-photometer (Varian Spectra AA-220FS) according to APHA (1998).

\section{RESULTS}

The populations of the heterotrophic and coliform bacteria at the onset and peak of the dry and wet seasons respectively showed that Isunpaiye spring had the highest count of $2.04 \times 10^{6} \mathrm{CFU} / \mathrm{ml}$ while Agadagidi spring had the least population of $0.4 \times 10^{6} \mathrm{CFU} / \mathrm{ml}$ heterotrophic bacteria at the onset of the dry season. At the peak of the dry season, population of heterotrophic bacteria reduced with the highest count of $0.84 \times 10^{6}$ $\mathrm{CFU} / \mathrm{ml}$ and lowest count of $0.14 \times 10^{6} \mathrm{CFU} / \mathrm{ml}$ recorded for Isunpaiye and Agadagidi springs.

During the rainy season, the population of the heterotrophic bacteria was highest $\left(4.0 \times 10^{6} \mathrm{CFU} / \mathrm{ml}\right)$ in Omi-ldu and lowest $\left(0.47 \times 10^{6} \mathrm{CFU} / \mathrm{ml}\right)$ in Arae. Isunpaiye and Gurusi recorded significantly high counts of $3.93 \times 10^{6} \mathrm{CFU} / \mathrm{ml}$ and $1.96 \times 10^{6} \mathrm{CFU} / \mathrm{ml}$ respectively. (Table 1)

The total count of coliform bacteria in the spring waters during the dry and wet (rainy) season showed that 
Table 2. Most probable number of coliforms per hundred milliliters of spring water samples. Mean MPN/100 ml sample per season.

\begin{tabular}{lcc}
\hline \multirow{2}{*}{ Sample source } & \multicolumn{2}{c}{ Mean MPN/100ml sample per season } \\
\cline { 2 - 3 } & $\begin{array}{c}\text { Rainy season March - } \\
\text { October mean } \pm \text { SD }\end{array}$ & $\begin{array}{c}\text { Dry season November - } \\
\text { February mean } \pm \text { SD }\end{array}$ \\
\hline Arae Spring & $11.459 \pm 1.51$ & $7.0 \pm 5.1$ \\
Agadagidi Spring & $11.1 \pm 2.16$ & $5.1 \pm 2.6$ \\
Akasabo Spring & $25.4 \pm 1.94$ & $15.2 \pm 1.8$ \\
Ashonmo Spring & $15.2 \pm 0.6$ & $8.3 \pm 3.2$ \\
Isunpaiye Spring & $65.5 \pm 1.17$ & $30.8 \pm 3.6$ \\
Gurusi Spring & $60.4 \pm 0.654$ & $32.1 \pm 1.2$ \\
Omi-idu & $76 \pm 2.1$ & $60 \pm 1.3$ \\
\hline
\end{tabular}

Isunpaiye had the highest population of $1.04 \times 10^{6}$ $\mathrm{CFU} / \mathrm{ml}$, while the least population of $0.19 \times 10^{6} \mathrm{CFU} / \mathrm{ml}$ was recorded for Agadagidi spring. At the peak of the dry season, Omi-Idu had the highest coliform count of $0.71 \mathrm{x}$ $10^{6} \mathrm{CFU} / \mathrm{ml}$, while Agadagidi had the lowest population of $0.083 \times 10^{6} \mathrm{CFU} / \mathrm{ml}$. During the rainy season, Omi-Idu had the highest $\left(1.91 \times 10^{6} \mathrm{CFU} / \mathrm{mL}\right)$ population of coliforms at the onset, but the population declined and Isunpaiye had the highest count of $2.8 \times 10^{6} \mathrm{CFU} / \mathrm{mL}$ at the peak of the season (Table 1).

The most probable number (MPN) of coliforms using the multiple tube fermentation test showed that the probable number of coliforms was higher during the rainy season than the dry season. Omi-idu had the highest MPN value of $76 \pm 2.1 \mathrm{MPN} / 100 \mathrm{~mL}$, while Agadagidi had the least number of $11.1 \pm 2.16$ coliforms per $100 \mathrm{~mL}$ of water sampled during the rainy season. During the dry season, Gurusi spring had the highest MPN estimate of $32.1 / 100 \mathrm{~mL}$, which is a little above $30.8 / 100 \mathrm{~mL}$ recorded for Isunpaiye. Agadagidi consistently had the lowest number of 5.1 coliforms per $100 \mathrm{~mL}$ of water sampled (Table 2).

Colour, temperature, turbidity, $\mathrm{pH}$, electrical conductivity, total solid, total dissolved solids, among others were some of the minerals constituents of the spring waters determined. The highest value of 51Pt Co for colour was recorded at Omi-Idu and lowest (8.0 Pt Co) at Ashonmo spring. Turbidity of water from the springs, showed the highest value of 11 NTU in Omi-ldu, while the lowest value of 3 NTU were in Akasabo, Ashomo and Gurusi, respectively. Omi-idu had the highest temperature of $27^{\circ} \mathrm{C}$ while the lowest temperature of $24^{\circ} \mathrm{C}$ was at Arae, Agadagidi, Akasabo, Ashonmo and Isunpaiye, respecttively. The highest $\mathrm{pH}$ of 8.3 was recorded in Arae and Gurusi springs, while the lowest value of 7.2 was at Akasabo. Electrical conductivity $\left(\mu \mathrm{Sm}^{-1}\right)$ was highest in Arae borehole with a value of $1.48 \mu \mathrm{S} / \mathrm{m}$ and the lowest value of $0.15 \mu \mathrm{S} / \mathrm{m}$ was in Gurusi spring. Arae had the highest value of $962 \mathrm{mg} / \mathrm{mL}$ of total dissolved solids (TDS), while the lowest value of $156 \mathrm{mg} / \mathrm{mL}$ was recorded for Ashonmo spring. Suspended solids in water samples were recorded to be highest in Omi-ldu and least at Ashomo. Hardness which is the ability of the water to form lather was highest in Arae and lowest in Gurusi spring. The level of $\mathrm{Cl}^{-}$and $\mathrm{NO}_{3}$ ions in water, showed the highest level of 48 and $24.6 \mathrm{mg} / \mathrm{L}$ at Arae and Akasabo, respectively (Table 3).

Evaluation of the presence of metal residue in selected spring waters were carried out. The selected springs were: Arae, Akasabo, Isunpaiye and Omi-idu springs. For magnesium, Arae had the highest value of $19.62 \mathrm{mg} / \mathrm{L}$ while Omi-ldu had the lowest value of $2.43 \mathrm{mg} / \mathrm{L}$. The presence of Iron in the water showed the highest residual concentration of $7.62 \mathrm{mg} / \mathrm{L}$ in Omi-idu and lowest concentration of $0.21 \mathrm{mg} / \mathrm{L}$ in Akasabo. Among the heavy metals, lead had the highest value of $2.46 \mathrm{mg} / \mathrm{L}$ at Akasabo while nickel residue was highest at Omi-idu and lowest in Isunpaiye at values of 0.71 and $0.24 \mathrm{mg} / \mathrm{L}$, respectively. Chromium ion $\left(\mathrm{Cr}^{3-}\right)$ was highest at Omi-idu and lowest at Arae spring. Selenium $(0.78 \mathrm{mg} / \mathrm{L})$ and cobalt $(0.09 \mathrm{mg} / \mathrm{L})$ were highest in Arae while the lowest residual concentrations of the two metals were recorded in Omi-Idu with values of 0.09 and $0.03 \mathrm{mg} / \mathrm{L}$ respectively. Highest residual concentration of vanadium was at Omi-idu while the lowest was at Akasabo (Table 4)

\section{DISCUSSION}

The high heterotrophic bacterial population during the rainy season is consistent with the findings of many workers (Bhatt et al., 1999; Radhika et al., 2004). They attributed the high population of heterotrophic bacteria during the rainy season to discharge and the washing of organic matter into water bodies. For springs, the water level will rise; hence more water will flow out from the discharge point. While during the dry season, the ground water table will recede thereby a low rate of flow and hence low level of contamination with organic matter (Nouyang et al., 2009). Also, the high coliform count in water during the rainy season is due primarily to discharge of organic matter into water (Nouyang et al., 
Table 3. Physicochemical properties of spring and borehole water from Ikare-Akoko communities.

\begin{tabular}{lcccccccc}
\hline Source/parameter & Arae & Agadagidi & Akasabo & Ashonmo & Isunpaiye & Gurusi & Omiidu & WHO (2011) Standard \\
\hline Colour (Pt.Co) & 13 & 16 & 12 & 8 & 17 & 11 & 51 & $15 \mathrm{Pt}$. Co \\
Temp $\left({ }^{\circ} \mathrm{C}\right)$ & 24 & 24 & 24 & 24 & 24 & 25 & 27 & $\mathrm{NS}$ \\
Turbidity (NTU) & 4 & 4 & 3 & 3 & 5 & 3 & 11 & 1.0 \\
$\mathrm{pH}$ & 8.3 & 7.3 & 7.2 & 7.5 & 7.4 & 8.3 & 8.1 & $6.5-8.5$ \\
EC $(\mu \mathrm{Sm})$ & 1.48 & 0.52 & 0.73 & 0.24 & 0.65 & 0.15 & 0.30 & 12 \\
TDS $(\mathrm{mg} / \mathrm{L})$ & 962 & 338.0 & 474.50 & 156 & 422.05 & 97.5 & 195.0 & $500 \mathrm{mg} / \mathrm{L}$ \\
TSS $(\mathrm{mg} / \mathrm{L})$ & 7 & 5 & 7 & 4 & 9 & 7 & 10 & $>10 \mathrm{mg} / \mathrm{L}$ \\
TS $(\mathrm{mg} / \mathrm{L})$ & 969.0 & 343.0 & 481.0 & 160 & 431.05 & 104.50 & 205.0 & \\
Hardness $(\mathrm{mg} / \mathrm{L})$ & 260 & 150 & 180 & 130 & 170 & 90 & 120 & $100-200 \mathrm{mg} / \mathrm{L}$ \\
Alkalinity $(\mathrm{mg} / \mathrm{L})$ & 148 & 100 & 100 & 100 & 110 & 100 & 132 & $500 \mathrm{mg} / \mathrm{L}$ \\
$\mathrm{Cl}^{-}(\mathrm{mg} / \mathrm{L})$ & 48 & 33 & 40 & 11 & 20 & 14 & 12 & $250 \mathrm{mg} / \mathrm{L}$ \\
$\mathrm{NO}_{3}(\mathrm{mg} / \mathrm{L})$ & 17.60 & 14.52 & 24.64 & 9.64 & 7.48 & 15.48 & 14.08 & $50 \mathrm{mg} / \mathrm{L}$ \\
\hline
\end{tabular}

Table 4. Metals load in selected spring water.

\begin{tabular}{lccccc}
\hline Metal (mg/L) & Arae Spring & Akasabo Spring & Isunpaiye Spring & Omi-idu Spring & $\begin{array}{c}\text { WHO (2011) guideline for drinking } \\
\text { water (mg/L) }\end{array}$ \\
\hline Aluminium & 0.002 & 0.002 & 0.004 & 0.005 & 0.004 \\
Magnesium & 19.62 & 8.88 & 7.47 & 2.43 & 7.47 \\
Iron & 0.45 & 0.21 & 1.08 & 7.62 & 0.3 \\
Copper & 0.249 & 0.216 & 0.270 & 0.264 & 2.0 \\
Manganese & 0.27 & 0.12 & 0.39 & 0.6 & 0.5 \\
Lead & 2.43 & 2.46 & 2.43 & 2.28 & 0.5 \\
Nickel & 0.39 & 0.39 & 0.24 & 0.71 & 0.07 \\
Chromium & 0.033 & 0.0621 & 0.0885 & 0.237 & 0.05 \\
Cadmium & 0.037 & 0.0621 & 0.0885 & 0.027 & 0.003 \\
Selenium & 0.78 & 0.12 & 0.42 & 0.09 & 0.04 \\
Cobalt & 0.09 & 0.03 & 0.06 & 0.03 & \\
Vanadium & 0.006 & 0.004 & 0.009 & 0.011 & \\
Zinc & 0.03 & 0.03 & 0.06 & 0.03 & 3.0 \\
\hline
\end{tabular}

2009) and since this water serve as the source of recharge water for most of the springs. The microbiological quality of spring water depends on the source rock and how deep is the ground aquifer that serves as the water recharge source.

Also, the high coliform indicates that human faecal material had contaminated the water due to human activities (Nouyang et al., 2009). Due to inadequate provision of tap water in some areas, this water is used for cleaning activities such as bathing, washing of clothes, car washings, etc. All these activities led to the discharge of waste into the spring water which will culminate in the proliferation of coliforms.

The high heterotrophic and coliform bacterial count in Omi-idu and Isunpaiye may be due to frequent human and animal contact with the springs, which leaves a negative impact on the springs (Taulo et al., 2008). Also, plant litters and droppings of domestic animals were observed very near the water especially at Omi-idu and Isunpaiye. This may be the source of coliform bacteria contamination of the springs and hence affecting the sanitary status of the water.

The lowest count of heterotrophs and coliforms in Agadagidi, shows that the spring has a high sanitary level as compared to the other springs. Although, Agadagidi does not meet the sanitary level prescribed by the WHO standard, the hygiene level can be improved upon so that potable water can be obtained from the spring.

The high MPN of coliforms recorded in the springs especially in Isunpaiye and Omi-idu in the rainy season than in the dry season, which suggests that animal and faecal matter may be discharged intermittently or on regular basis by human and animal visiting the springs for various purposes. Also, the spring water discharge area for Isunpaiye does not have a protective embankment thereby prone to contamination due to run-off (Patil et al., 
2004).

The $\mathrm{pH}$ range of 7.2 to 8.3 which are tending towards the alkaline range may be due to the use of detergents for the washing of clothes and utensils. Also, wash-off from area of the spring containing calcite and dolomite minerals could also be partly responsible for this (Paka and Rao, 1997). The high $\mathrm{pH}$ range recorded in the study is within the $\mathrm{WHO}$ standard for potable water $(\mathrm{WHO}$, 2011).

Electrical conductivity $(\mu \mathrm{S} / \mathrm{m})$ was found to be below the WHO (2011) standard benchmark of $12 \mu \mathrm{S} / \mathrm{m}$ for potable water. Previous studies with high electrical conductivity in some coastal areas of Lagos and Warri have been reported but this was attributed to the intrusion of water from the Atlantic ocean into the wells as the water is being harvested (Agatemor and Agatemor, 2010). This suggests that the spring waters are not salty.

Higher alkalinity value above $100 \mathrm{mg} / \mathrm{L}$ has been considered nutritionally rich (Srivastava, 2002). On the basis of this, Arae, Isunpaiye and Omi-ldu are considered to be eutrophic. This further suggests that organic matter is directly or indirectly introduced into the springs by individuals fetching the water for washing of clothes and other uses.

The highest turbidity value of 11 NTU recorded at Omiidu is quiet consistent with the findings of Agatemor and Agatemor (2010). They reported similar values in well waters in Lagos. The level of nitrate reported in this study is far below the WHO standard, but it suggests that the springs are slightly contaminated with nitrogenous wastes. Higher total dissolved solids values than that reported in this study had been reported by Edet and Okereke (2001) in the coastal region.

High lead and vanadium in Omi-idu may not be unconnected to anthropogenic activities close to the spring, like discharge of automotive fuel, grease and car battery water (Agatemor and Agatemor, 2010). It was observed that Omi-idu is located very close to a car wash where automotive fuel, grease and batteries are discharged into the spring.

This study shows that the general belief in the rural areas that spring waters are clean and potable is not absolutely true and that spring water despite being groundwater can still be contaminated by faecal coliforms and mineral elements. This point to the fact that users especially children are exposed to serious health risk. Hence before consumption, treatment should be seriously considered, so as to eliminate possible risk factors associated with unclean water.

\section{REFERENCES}

Ademoroti CMA (1996). Standard methods for water and effluents Analysis. Foludex Press Ltd. Ibadan, Nigeria.

Agatemor, C. and Agatemor, U.M. 2010. Physico-chemical characteristics of well waters in four urban centers in Southern Nigeria. Environmentalist 30:333-339.
American Public Health Association, American Water Works Association, Water Pollution Control Federation (APHA/AWWA/WPCF) (1998). Sanitary Method for the Examination of Water and Wastewater. $20^{\text {th }}$ Edn. Washington DC, USA.

APHA (1992). Standard methods for Examination of water and wastewater. American Public Health Association, Washington, DC, USA.

APHA (1998). Standard Methods for Examination of water and wastewater. $19^{\mathrm{TH}}$ edition, American Public Health Association, Washington, DC, USA.

Bhatt LR, Lacoul P, Lekhak HB and Jha PK (1999). Physicochemical charac- teristics and phytoplanktons of Taudaha Lake, Kathmandu, Pollut. Res. 18:353-358.

Chilton PJ, West JM (1992). Aquifers as environments for microbial activity. In: Proceedings of the International Symposium on Environmental Aspects of Pesticide Microbiology, Sigtuna, Sweden, 293-304.

Edet AE, Okereke CS (2001). A regional study of saltwater intrusion in southeastern Nigeria based on the analysis of geoelectrical and hydrochemical data. Environ. Geol. 40:1278-1289.

Ford TE, Colwell RR (1996). A global decline in Microbiological safety of water: A call for action. American Academy of Microbiology. American Society for Microbiology, Washington DC USA. p. 7.

Foster S, Hirata R, Misra S, Garduño H (2010). Urban groundwater use policy balancing the benefits and risks in developing nations. GlobalWater Mate Strategic Overview series No 3. World Bank Washington DC, USA.

Freeze RA, Cherry JA (1979). Groundwater. Prentice-Hall, Englewood Cliffs, New Jersey. pp. 604

Nkansah MA, Ephraim JH (2009). Chemical quality of groundwater drawn from boreholes in Ashanti region of Ghana. Groundwater and climate in Africa. Proceedings of the Kampala Conference, June, 2008. Int. Association of Hydrology Society Publication No. 334. pp. 36-39.

Nouyang ME, Nola M, NjineT, Zebaze Togoutet SH, Djaousda M, Djah $M$ (2009). The influence of hydrochemistry on the distribution of pathogenic strains of Escherichia coli in urban groundwater of Yaounde, Cameroon. Proceedings of the Groundwater and Climate in Africa Conference, Kampala Uganda, June, 2008. Int. Assoc. Hydrol. Soc. Pub. No. 334

NPC (2001). National Population Commission Census 2001.

Obiri-Danso K, Adjei B, Stanley KN, Jones K. (2009). Microbiological quality and metal levels in wells and boreholes water in some periurban communities in Kunasi Ghana. Afr. J. Environ Sci. Technol. Vol. 3(1). pp. 59-66.

Paka S, Rao AN (1997). Interrelationship of physicochemical factors of a pond. J. Environ. Biol. 18:67-72.

Patil PR, Chaudhari, DN and Kinage MS (2004). Water quality status of Padmalaya lakes, Erondal at Jalgaon District, Maharashta state. Environ. Ecol. 22:65-68

Radhika CG, Mini J, Gangaderr T (2004). Studies on abiotic parameters of a tropical fresh water lake - Vellayani Lake, Thiruvanthapuran District, Kerala. Pollut. Res. 23:49-63.

Srivastsava ML (2002). Physicochemical and microbiological character of water. Daya Publishing House, New Delhi, India. pp. 63.

Taulo S, Wetlesen A, Abrahamsen R, Mkakosya R, Kulunlanga G (2008). Microbiological quality of water, associated management practices and risk at source, transport and storage points in a rural community of Lungwena, Malawi. Afr. J. Microbiol. Res. Vol. 2 131137.

Taylor RG, Howard KWF (1996). Groundwater recharge in the Victoria Nile basin of East Africa: support for the soil moisture balance method using stable isotope and flow modeling studies. J. Hydrol.180:31-53.

USGS (2000). Domestic water use in the USA .United States Geological Society Circular 1268.

WHO (2011). Guidelines for drinking-water quality. Fourth edition. World Health Organisation Publication. Geneva, Switzerland. pp. 307- 447. 